This item was submitted to Loughborough's Research Repository by the author.

Items in Figshare are protected by copyright, with all rights reserved, unless otherwise indicated.

\title{
Assessing activated sludge morphology by laser and image analysis
}

PLEASE CITE THE PUBLISHED VERSION

http://dx.doi.org/10.1680/wama.2010.163.3.139

PUBLISHER

(C) ICE Publishing

VERSION

VoR (Version of Record)

LICENCE

CC BY-NC-ND 4.0

REPOSITORY RECORD

Wu, Jun, and Andrew D. Wheatley. 2019. "Assessing Activated Sludge Morphology by Laser and Image Analysis". figshare. https://hdl.handle.net/2134/15249. 
This item was submitted to Loughborough's Institutional Repository (https://dspace.lboro.ac.uk/) by the author and is made available under the following Creative Commons Licence conditions.

\section{creative
commons}

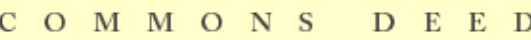

Attribution-NonCommercial-NoDerivs 2.5

You are free:

- to copy, distribute, display, and perform the work

Under the following conditions:

Attribution. You must attribute the work in the manner specified b the author or licensor.

Noncommercial. You may not use this work for commercial purposes.

No Derivative Works. You may not alter, transform, or build upon this work.

- For any reuse or distribution, you must make clear to others the license terms of this work.

- Any of these conditions can be waived if you get permission from the copyright holder.

Your fair use and other rights are in no way affected by the above.

This is a human-readable summary of the Leqal Code (the full license).

\section{Disclaimer 만}

For the full text of this licence, please go to: http://creativecommons.org/licenses/by-nc-nd/2.5/ 


\title{
Assessing activated sludge morphology by laser and image analysis
}

\author{
J. Wu PhD and A. Wheatley PhD
}

An excess of filamentous bacteria is a common settlement problem affecting the activated sludge process. In this study activated sludge morphology was monitored by image analysis and laser scattering. These were compared with the conventional sludge volume index. Good correlations between the two optical techniques for floc size were found when the small and interfering particles $(<\mathbf{5 0} \boldsymbol{\mu m})$ were removed from the analysis (activated sludge size $100-500 \mu \mathrm{m}$ ). A simpler image analysis procedure was developed using common software and equipment available in most laboratories. This should enable reproducible microbial morphology measurements to be used more widely routinely to predict the onset of poor settlement. The image analysis was used to determine the standard index of filamentinduced poor settlement, namely the total extended filament length. The results in common with some previously noted work did not show a simple link between either floc size or total extended filament length and sludge volume index. A new indicator of excess filaments is suggested, based on the frequency of occurrence of just the long extended filaments

(> $100 \mu \mathrm{m}$ ) which was shown to give better prediction of poor settlement (bulking).

\section{INTRODUCTION}

The activated sludge process is the most common wastewater treatment process (Tchobanoglous et al., 2002). The biomass in activated sludge are self-flocculating colonies due to the type of bacteria and charged extra cellular polymer (Martins et al., 2005). Particulate and dissolved pollutants removed from the wastewater are converted or held in the biomass which is then usually separated from the cleaned effluent by simple settlement. A common factor causing poor settlement is excessive filamentous growth (Martins et al., 2005) in the colonies. According to the backbone theory of floc formation (Cenens et al., 2000; Sezgin and Jenkins, 1978), the filaments normally provide binding and support for the floc and it is suggested that bacterial flocs need this reinforcement to resist shear and so settle rapidly. If, however, the filaments grow too well and extend beyond the floc structure then this prevents the formation of closely packed compact flocs. There are a number of possible causes of excessive filament growth or bulking activated sludge (Gerardi, 2003; Martins et al., 2005), but a major factor is a lack of easily assimilible substrate. Previous work reports bulking has become a more extensive problem as loads were reduced to promote nutrient removal and as sewage became weaker (Eikelboom, 1975; Madoni et al., 2000; Martins et al., 2005). Designs have been modified to eliminate primary settlement, induce plug flow or to include separate additions of feed to increase soluble substrate concentrations and so promote selection of well settling cultures (Ekama, 1997).

Microscopic examination is the standard method of assessing the morphological state of the floc to predict poor settlement (Jenkins et al., 1993) but it is a tedious, time-consuming task vulnerable to subjective interpretation. This limits its usefulness in the development of models and research on microbial flocculation. Automated image analysis has been suggested for this task (Da Motta et al., 2001) and recently it has been introduced into simple laboratory software (Matlab, 2004) and can be carried out quickly with standard microscopes.

Laser particle size analysis is an alternative for floc size analysis and is also now frequently used in water laboratories to predict settlement rates and characterise particles (Jarvis et al., 2005). This paper reports on measuring floc size and characteristics by simplified image analysis and laser scattering compared with conventional settlement rate (SVI).

\section{METHODS}

\section{I. Activated sludge samples}

The sludge volume index (SVI) was determined by standard methods (APHA, 1995) and defined as the volume in millilitres occupied by $1 \mathrm{~g}$ of biomass after 30 min settling.

The activated sludge samples were collected from the combined outflows of the aeration tanks at the local sewage treatment works. The optical analysis could then be carried out within the hour. The treatment works serves mainly a domestic population equivalent of 70000 with a dry weather flow (DWF) of $21 \mathrm{Ml} /$ day and maximum flow to treatment of three times the DWF $(699 \mathrm{l} / \mathrm{s})$. The treatment process is conventional with screening, grit separation and primary settlement followed by plug flow aeration lanes. There is a separate tank for denitrification and as a selector (Tchobanoglous et al., 2002) where the settled sewage is pre-mixed with return activated sludge (RAS) in the usual approximately $1: 1$ ratio. The activated sludge is settled in six final clarifiers with flow velocity of $1.5 \mathrm{~m} / \mathrm{h}$ at DWF. Samples were collected over a two and a half year period and 
additional detail can be found in the thesis resulting from this work (Wu, 2008).

\subsection{Image acquisition}

A Zeiss (AxioSkop40) microscope fitted with a Zeiss AxioCam MRc5 digital camera was used to capture the image of activated sludge. The image was originally in a $2584 \times 1963$ pixel format which was reduced to $1024 \times 767$ pixels to speed up computation time for image processing. Characterisation of the image was carried out using the image analysis toolbox now in Matlab 7.0 (Matlab, 2004).

In order to obtain reproducible results, a number of flocs need to be sized. Da Motta et al. (2001) found 50 images were required for statistically sensible results. Liwarska-Bizukojc and Bizukojc (2006) reported that 40 images gave acceptable confidence limits. Liao et al. (2006) on the other hand noted that a minimum of 1000 flocs needed counting to reach an acceptable standard deviation. The effect of the number of images examined on floc size and standard deviation from the present work are shown in Figure 1. It can be seen that after 50 images, the standard deviation was reduced to less than $\pm 10 \%$ of the mean ( $\pm 18 \%$ after 30 images).

Activated sludge flocs are complex three-dimensional structures and the size measured depends on the orientation of the flocs presented to the digital camera (Jarvis et al., 2005). The British Standard for quantitative microscope counting therefore suggests a minimum of 625 particles to obtain representative size distribution (BSI, 1963). In these results, the analysis of 50 images corresponded to around 630 flocs. Therefore 50 images were chosen for the current analysis based on the data in Figure 1 and these previous recommendations.

\subsection{Floc size measurement}

Image sizes in pixel units were converted into micrometres by stage graticule $(100 \mu \mathrm{m})$. At the selected magnification $(\times 10$ eyepiece $\times 10$ stage), $1 \mu \mathrm{m}$ was equal to 1.67 pixels.

\subsubsection{Floc size measurement. Figure 2(a) is a typical} unstained brightfield micrograph of the activated sludge. To define and dimension the flocs the contrast between the floc and background was enhanced using the thresholding tool in the Matlab software. Thresholding was based on contrast between individual pixels using the greyscale. Images were

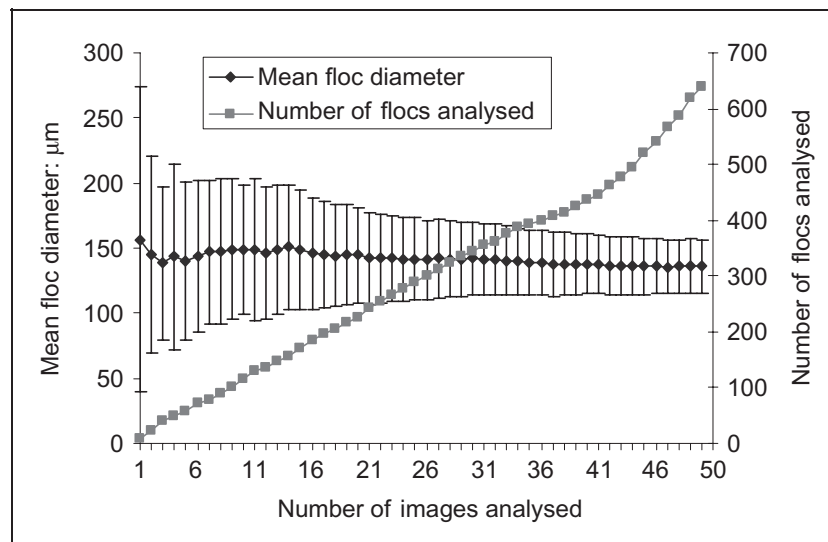

Figure I. Average and standard deviation in floc size with number of images analysed counted as 'objects' if their darkness was greater than an adjustable threshold value, otherwise they were discounted as 'background' pixels. The process is demonstrated in Figure 2 where the original image (Figure 2(a)) is converted to a binary phase contrast image (Figure 2(b)) which exaggerates the difference between the filaments and larger flocs.

Flocculated activated sludge is much larger than filaments and other particles and the image analysis software also includes a standard tool for defining and removing irrelevant particles called the 'opening' operation (Matlab, 2004; Russ, 1999). The limits as to what should be removed can be set by experience but also by default. The cut-off sizes recommended in the handbook (Russ, 1999) for example, were $0 \cdot 1 \%$ of the size of total field of view, which in these experiments would be equivalent to a diameter of $52 \mu \mathrm{m}(1024 \times 768 \times 0 \cdot 1 \%)$, which is larger than many pinpoint flocs (Ekama, 1997; Jenkins et al., 1993). Experiments were therefore carried out at a range of cut-off sizes of $0 \cdot 1,0 \cdot 01$ and $0 \cdot 001 \%$. These were equivalent to particles of 52, 16.7 and $5 \cdot 2 \mu \mathrm{m}$, respectively. An example of the results with these levels of noise removal is shown later in the discussion section (see Figure 4 below), where they are also compared with laser particle size analysis. Two cycles of noise removal were chosen (see also results and discussion section on image analysis) which is equivalent to removing objects smaller than $0 \cdot 01 \%$ of the total area (16.7 $\mu \mathrm{m}$ diameter). Example results of this are shown in Figure 2(c). The area in pixels of the remaining particles, defined as flocs, was then measured in the next stage (Figure 2(d)).

\subsubsection{Measuring filamentous bacteria. The filaments and} noise data cut during the 'opening' operation to measure floc size were retained separately for analysis of filament length. Figure 3(a) shows the same sample as Figure 2(b) but in this case the floc material can be removed as described previously to leave the filaments as shown in Figure 3(b). The small noise particles (non floc and non filament) are easier to identify when isolated from the flocs (Figure 3(b)). The creation of this separate file for filament analysis also allows a different size exclusion to be used in the Matlab opening function. In the case of the filaments this was set to remove objects smaller than the filament diameter at 2 pixels $(3.5 \mu \mathrm{m})$. The filaments were then skeletonised using another tool in the Matlab to a single pixel width shown in Figure 3(c), which then allows filament length to be measured as in Figure 3(d).

The proportion of filaments in the floc was measured by adding together all the filament lengths in the image as in Figure 3(d). The total extended filament length (TEFL) was initially measured based on $\mu \mathrm{m} /$ image and was converted to $\mu \mathrm{m} / \mathrm{ml}$ assuming that a cover slip gives $200 \mu \mathrm{m}$ depth $(1024 \times 768$ pixels $=1710 \mu \mathrm{m} \times 1280 \mu \mathrm{m})$ and therefore each image has a volume of 0.00044 ml). Extended filament length beyond the floc is thought to reduce settlement by preventing compression and consolidation of activated sludge floc. Sezgin and Jenkins (1978), Palm et al. (1980) and Lee et al. (1982) have suggested using TEFL beyond floc to predict sludge settleability.

\subsection{Laser-scattering measurement}

The Malvern Mastersizer 2000 has become a routine method of measuring particles in water (Govoreanu et al., 2004; Nopens et 


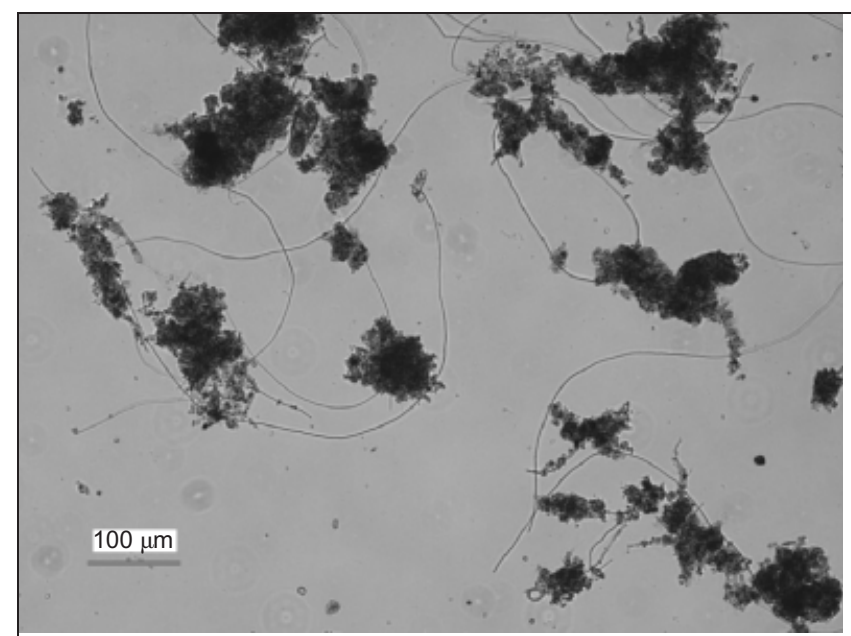

(a)

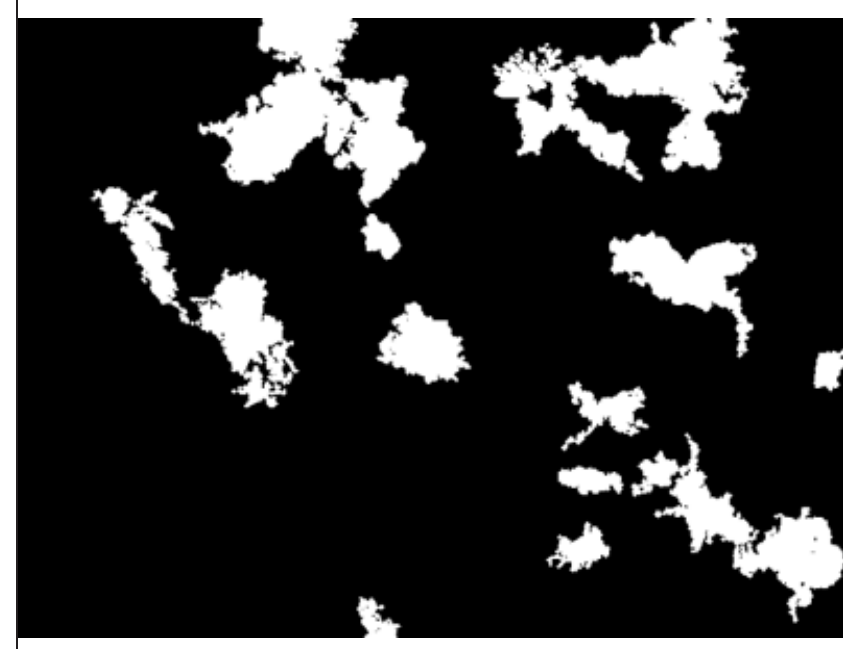

(c)

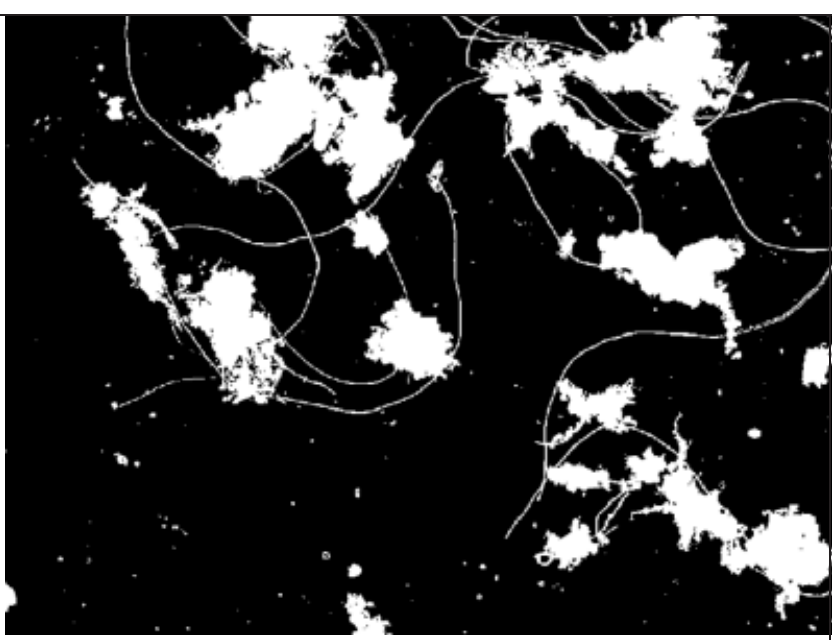

(b)

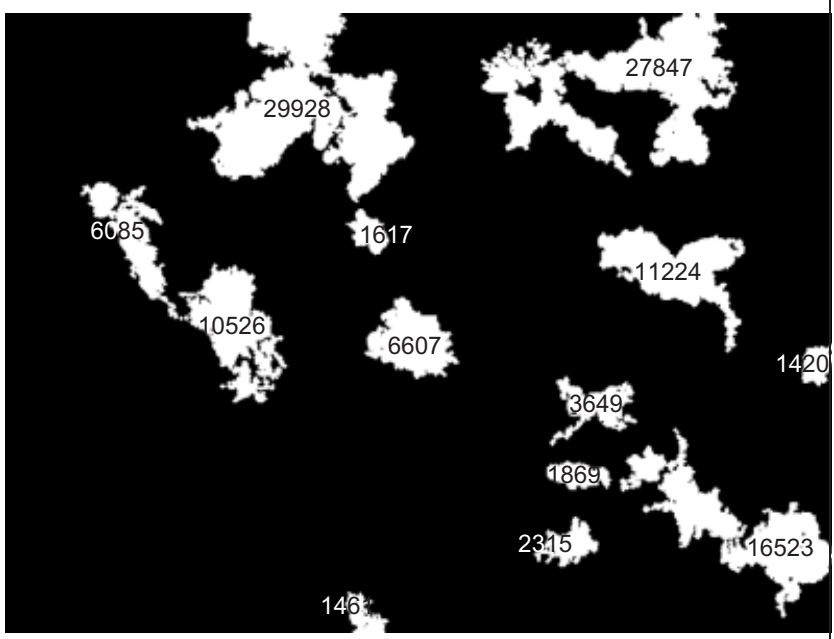

(d)

Figure 2. Sequence of steps used to measure floc size: (a) original image; (b) thresholding into binary image; (c) removing noise and filaments; (d) measuring the floc

al., 2002). The machine is simple to use for particle size measurements from 0.02 to $2000 \mu \mathrm{m}$. If too much of the laser beam is obscured by activated sludge then multiple scattering from particles may occur giving bias. If there is too low a concentration then insufficient signal will be detected and the precision will be adversely affected. Standardised operating procedures (Govoreanu et al., 2004) have been published for activated sludge and 8-10\% obscuration has been reported to give good results (Nopens et al. 2002). Following further tests on the activated sludge this was also used here. Tap water was added to the sample as it re-circulated through the Malvern Mastersizer until this obscuration was attained. Tap water was chosen instead of membrane-filtered final effluent to speed up the analysis (total dissolved salts (TDS) of tap water, $220 \mathrm{mg} / \mathrm{l}$; TDS of final effluent, $410 \mathrm{mg} / \mathrm{l})$. It was assumed that the ionic differences between tap water and final effluent would be less influential than sample ageing. Using tap water enabled the particle size measurements to be made within an hour of the sample being taken.

The Mastersizer does not analyse floc shape although it is suggested that this interpretation may be possible from the particle size distribution and their relative numbers and volumes (Govoreanu et al., 2004; Nopens et al., 2002; Thompson and Forster, 2003).

\section{RESULTS AND DISCUSSION}

\section{I. Comparison of the image analysis and the laser} scattering results

Figure 4 compares the activated sludge floc size distribution measured by both image analysis and laser scattering. The four different noise removal cut-off sizes described in the methods are compared (these were: no removal of small particles and $0 \cdot 1,0 \cdot 01$ and $0 \cdot 001 \%$ removal of image area which were equivalent to removing particle sizes of 52, 16.7 and $5 \cdot 2 \mu \mathrm{m}$, respectively). The agreement between the two methods improved as the smaller particles are removed. With no noise removal the image analysis showed a bimodal distribution with a stronger bias towards the single pixel particles $(1.67 \mu \mathrm{m})$ than the laser scatter, namely 33\% compared with 20\% of total numbers at $5 \mu \mathrm{m}$ or less. The Malvern Mastersizer differentiates particles into a limited number of size categories (100 although adjustable). It also normalises all the data to a percentage of 


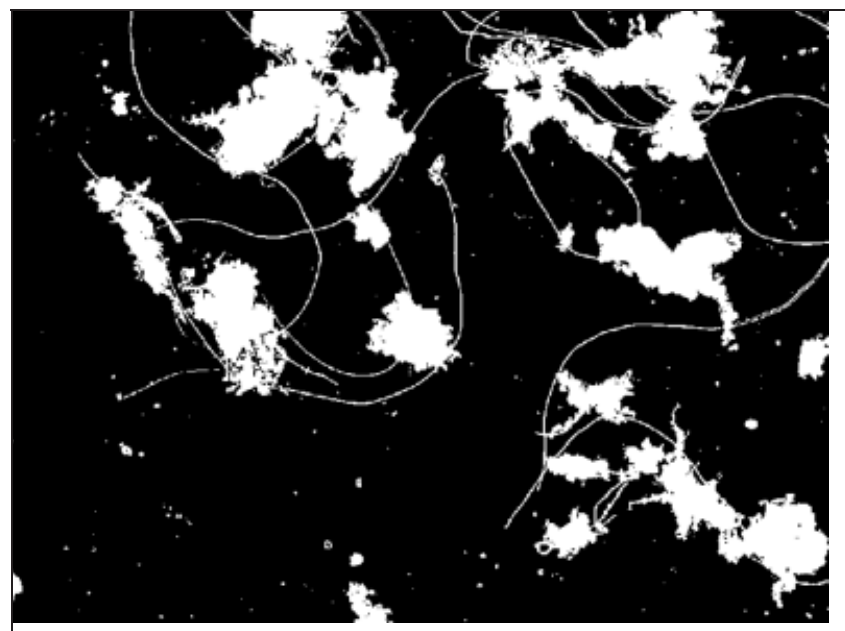

(a)

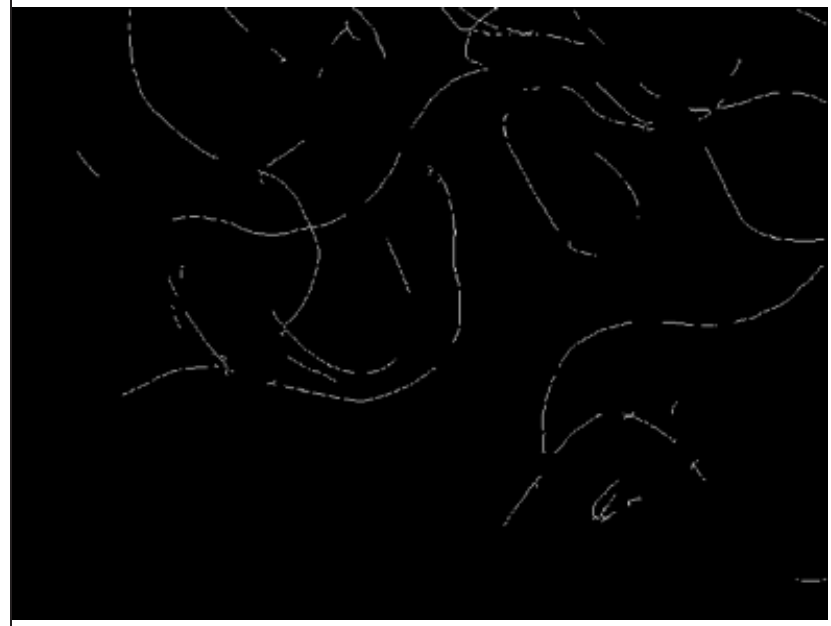

(c)

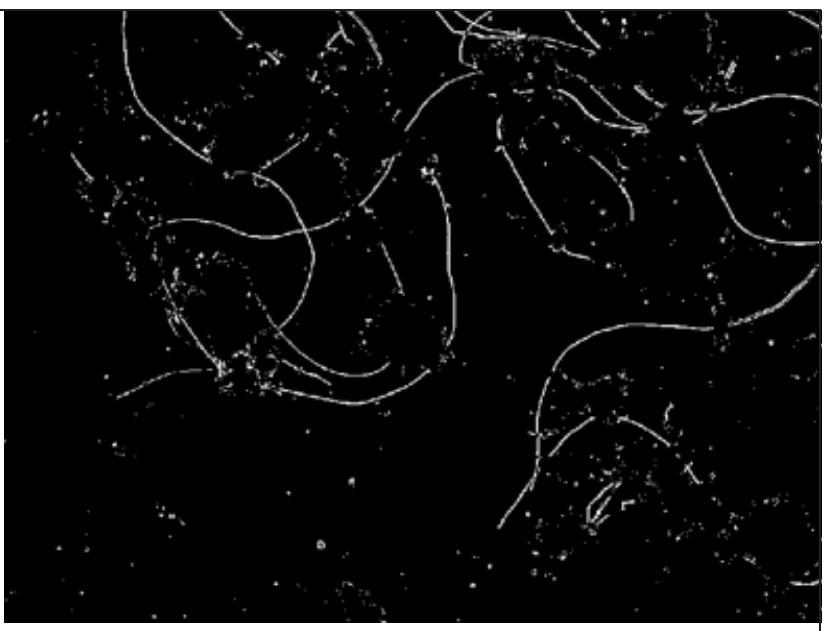

(b)

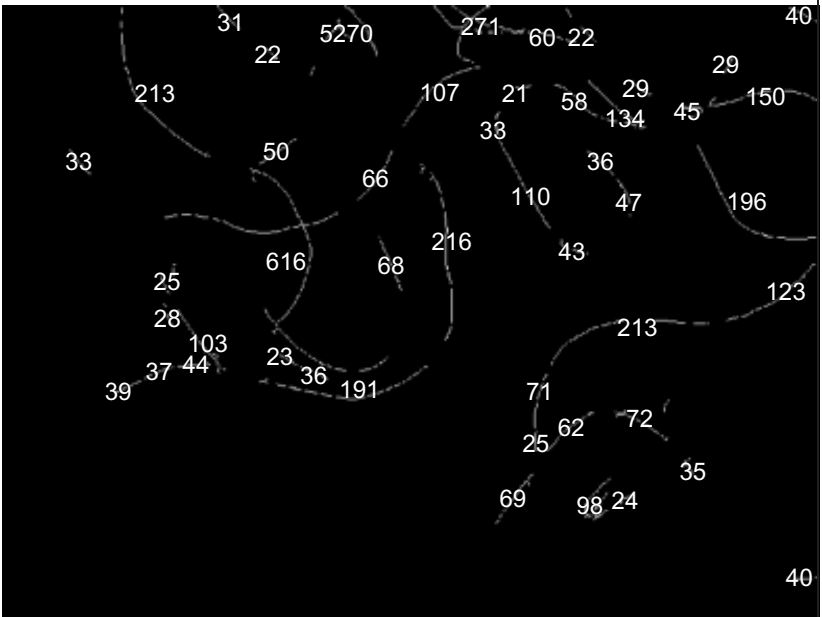

(d)

Figure 3. Sequence of steps used for measuring filament length: (a) thresholding into binary image; (b) extracting filamentous bacteria; (c) noise removal, skeletonisation; (d) measurement

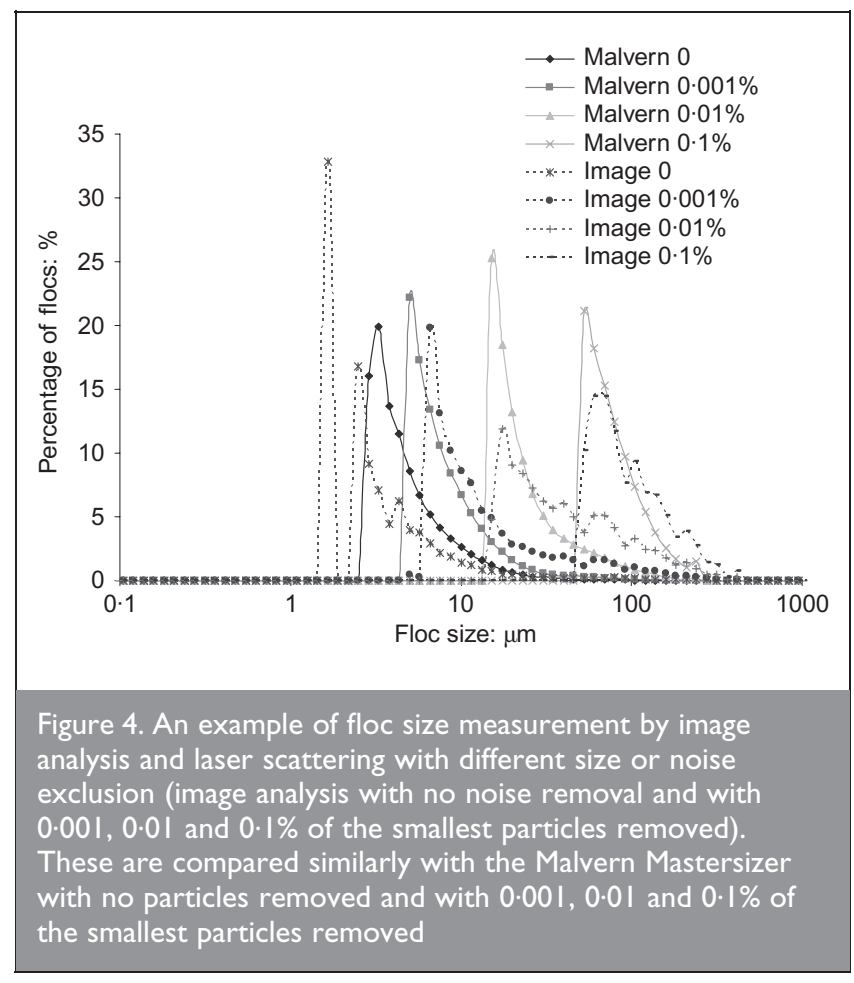

the total count and these factors are responsible for the smoother curves at the larger particle sizes.

In previous work comparing these two techniques to sizeactivated sludge flocs, it was recommended that data on particle sizes less than $5 \mu \mathrm{m}$ were excluded (Govoreanu et al., 2004) to obtain realistic floc sizes. Removing the flocs smaller than $16.7 \mu \mathrm{m}(0.01 \%$ of image area) from the data of a typical sample in Figure 4 produced a similar median floc size $(25 \mu \mathrm{m})$ by both techniques and to that reported by Govoreanu et al. (2004) $(25-30 \mu \mathrm{m})$, although this is still smaller than typical activated sludge flocs sizes reported by microscopy (150$300 \mu \mathrm{m}$; Martins et al. (2005)). The present data (Figure 4) suggest that in order to produce floc sizes that are more comparable with optical microscopy then particles smaller than $52 \mu \mathrm{m}$ (or $0 \cdot 1 \%$ of area) may need to be excluded, similar to the handbook recommendation. Govoreanu et al. (2004) made no comparisons with previous optical microscopy.

Removing particles less than $52 \mu \mathrm{m}$ may be justified for monitoring settlement but it would be interesting to use these two particle size techniques at the smaller sizes to predict final effluent quality in comparison with the conventional parameters. 


\subsection{Comparison of size measurements with settlement properties}

The ratio of floc area to filament length (FA/FL) by image analysis (average of 50 measurements for each data point as noted in the methods) was used to compare with settlement measured by the SVI tests. The floc area used in the calculation (FA) was the sum of the total floc area $(<16.7 \mu \mathrm{m}$ diameter particles ignored) and the sum of all the filament lengths beyond the flocs (TEFL). Adding the filament lengths together (TEFL) has been suggested as the standard method of predicting settlement (see also Methods section). Figure 5 shows the FA/FL from different samples selected to cover the range of SVI encountered. Increases in FA/FL value show a trend with reductions in SVI. There was a significant increase in SVI as the floc to filament ratio dropped below 100. It is widely accepted that the floc size should affect the settling velocity and SVI (Sezgin and Jenkins, 1978) but a plot of the floc area with SVI shown in Figure 6 suggests the filaments were the more important factor as might be anticipated from the basic theory (Sezgin and Jenkins, 1978). Others have also found that there are problems with simple links between either total numbers of filaments or floc size and settlement. Da Motta et al. (2001), for example, monitored sludge settling and floc characteristics (area and shape) for 13 months at a full-scale plant. They reported that a good correlation between floc morphology and settlement was only obtained during abnormal conditions when the plant was hydraulically overloaded and SVI above 200. In
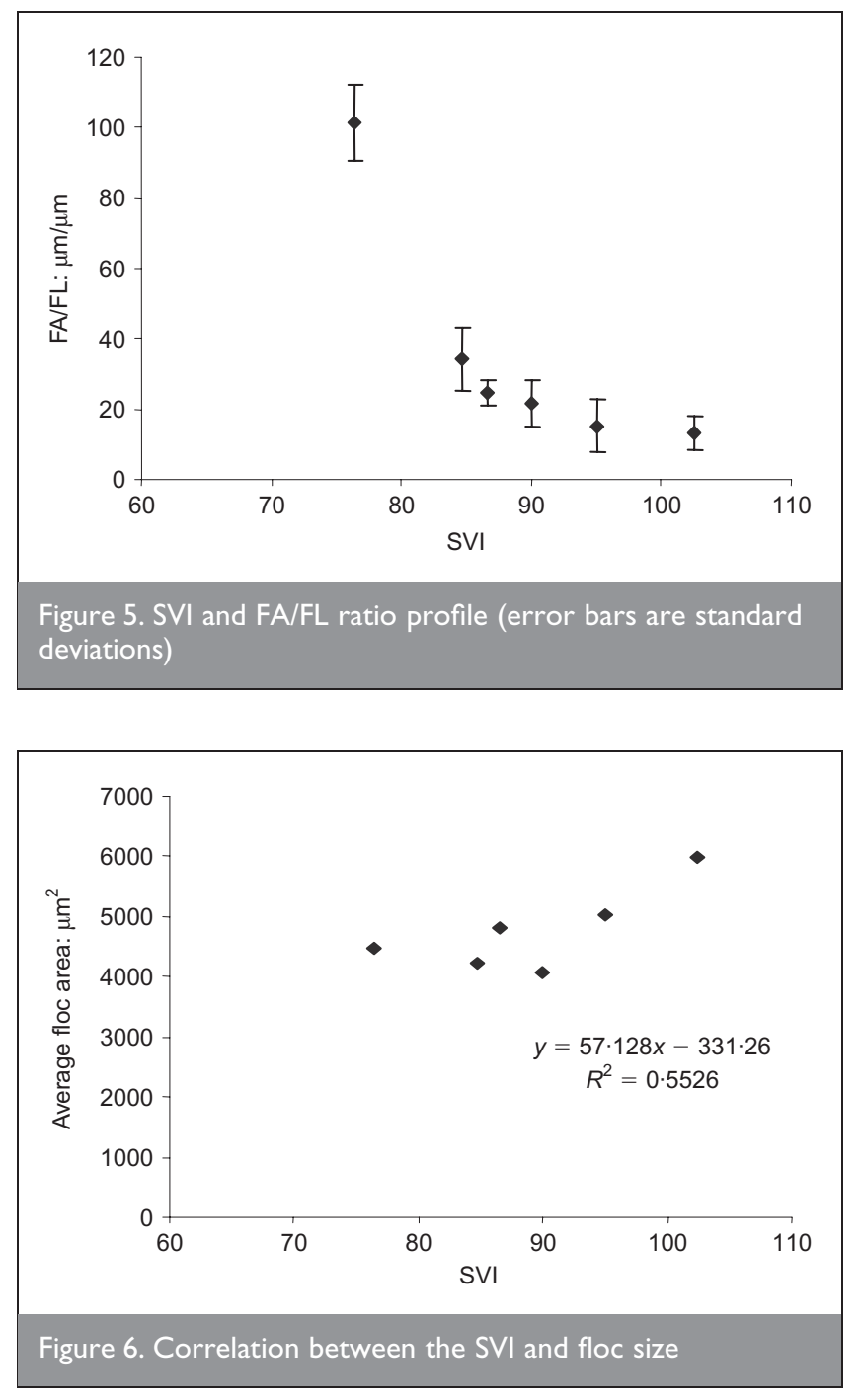

another example from a 3 year full-scale study (Wilen et al., 2008) it was suggested that the chemical make-up and temperature played a major role in settlement. Thompson and Forster (2003) were also unable to link filament abundance with stirred SVI (SSVI); they suggested a trend between settlement and surface charge of the floc. This means there are doubts about using general morphology parameters such as FA/ FL, combined filament length or floc size analysis; alone they are not enough to predict activated sludge settleability.

Other factors such as the fractal dimension, drag coefficient charge and floc density will affect the settling velocity. Furthermore, there may be flocculation within the SVI test with large flocs sweeping up much smaller material as they settle. It was observed during SVI tests that larger flocs precipitated rapidly and collected smaller particles during the first 1015 min of settlement. In the real dynamic conditions of a settling tank however things might be different and the stirred sludge volume index (SSVI) (APHA, 1995) test might produce different results. This requires further analysis.

\subsection{Floc size and filament length distribution}

Figure 7 shows a plot and potential correlation between TEFL and SVI when measured over the range suggested by Lee et al. (1982). Lee et al. noted a linear correlation below SVI 200 and exponential when above (Figure 8).

The present data and those reported by Lee et al. (1982) however show that SVI was less sensitive to TEFL in the

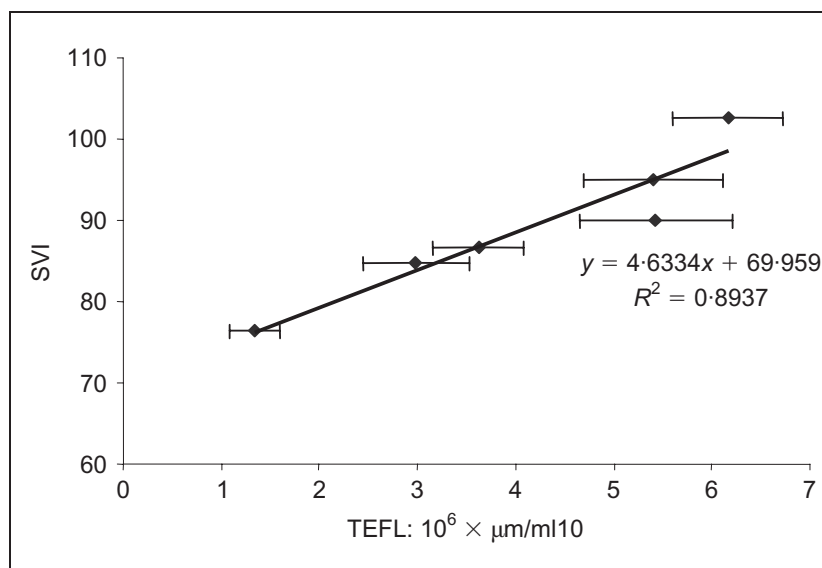

Figure 7. Correlation between the TEFL and SVI (error bars are standard deviation)

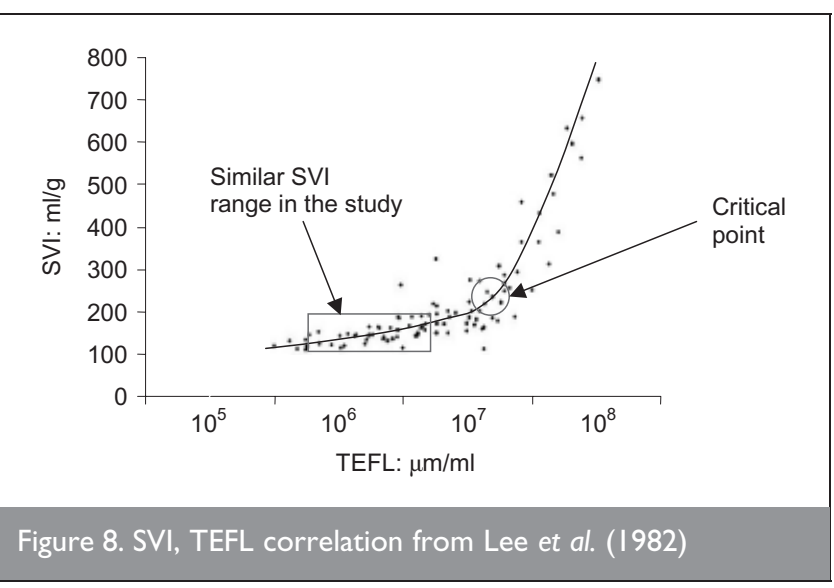


normal wastewater treatment plant operating range (indicated by the rectangle) an SVI above 200 would be debilitating for most activated sludge plants (Palm et al., 1980). These results are expressed as the sum of the extended filament length (TEFL) and the Lee et al. (1982) results show a sharp inflexion at $10^{8} \mu \mathrm{m}$ of filaments per millilitre. As noted previously on discussion of floc size distributions, a large number of small filaments could introduce bias in the results. An alternative to the total or summed filament length (TEFL) could be to focus on just the larger filaments and this effect is shown in Figure 9. There is a trend between higher SVI and long filaments (100$1000 \mu \mathrm{m})$. For example when the SVI was at its lowest (76) there were very few filaments above $60 \mu \mathrm{m}$ and as the filament length increased towards and above $100 \mu \mathrm{m}$ the SVI deteriorated. This is supported by the theory that it is the long filaments which will prevent close packing of the flocs and compression rather than the total number of filaments or TEFL.

A comparable plot of floc diameter with SVI is shown in Figure 10 and unlike filament length, there is no apparent correlation between the larger floc size and SVI. This interpretation is corroborated by the Da Motta et al. (2001) results that linked SVI with significant increases in filament length but not floc diameter.

\section{CONCLUSION AND RECOMMENDATIONS}

The size of activated sludge flocs was analysed using laser and image analysis. The analysis was developed with simple, standard commercial equipment and software now available in most laboratories. Both techniques were shown to give reliable

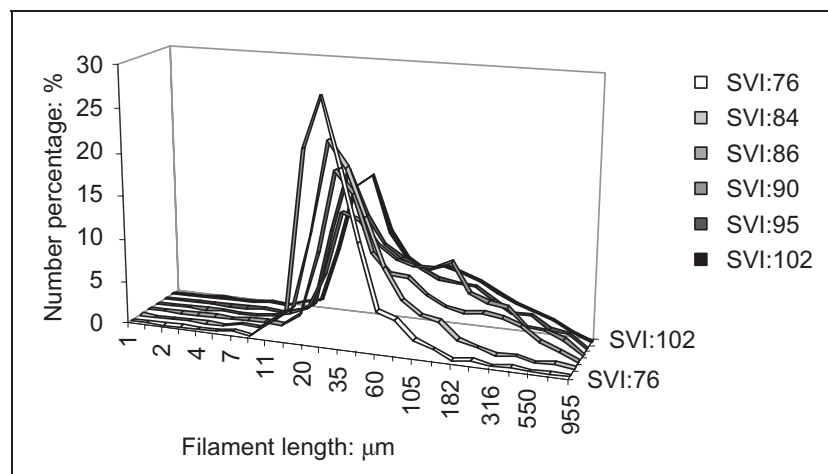

Figure 9 . Filament size distribution of activated sludge samples

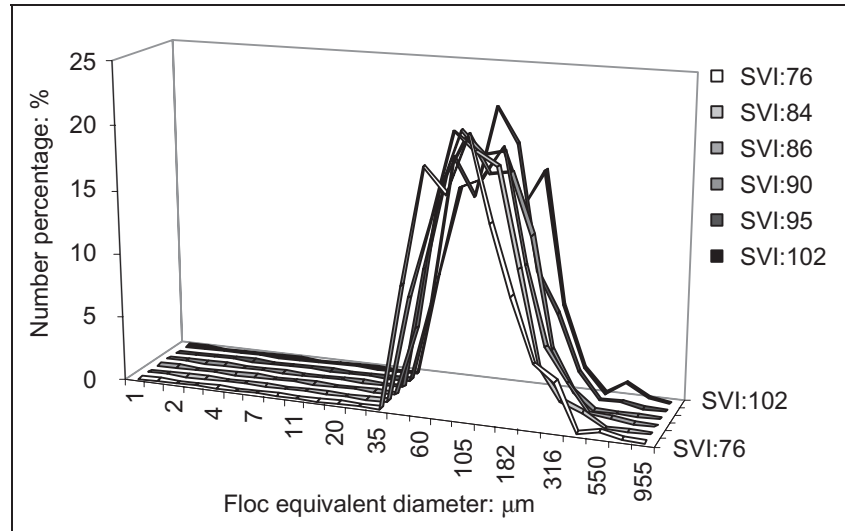

Figure 10. Floc size distribution of activated sludge samples and comparable results when adjusted for the bias caused by small particles. It was therefore suggested that particles $<50 \mu \mathrm{m}$ should be ignored when determining the average size of activated sludge flocs.

Neither simple floc size or the standard (TEFL) could be used to predict settlement. The results presented were from a standard, domestic, plug flow denitrifying plant with well-settling sludge (SVI < 100). Other previous work reviewed has suggested SVI and settlement need to be outside the normal operating range $(>200)$ in order for floc size and TEFL to be simply correlated with settlement.

Simplification of filament analysis to measure just the proportion and presence of long filaments $(>100 \mu \mathrm{m})$ was suggested. This gave a better indication of settlement than the common standard TEFL or floc size for normal operating plant (SVI < 200).

Further work is required to determine whether laser particle size distribution as well as image analysis can be adapted to differentiate long filaments.

\section{REFERENCES}

APHA (American Public Health Association) (1995) Standard Methods for the Examination of Water and Wastewater, 19th edn. APHA, Washington, DC, USA.

BSI (British Standards Institution) (1963) BS3406: Methods for determination of particle size distribution. BSI, London.

Cenens C, Smets IY, Ryckaert VG and van Impe JF (2000) Modelling the competition between floc-forming and filamentous bacteria in activated sludge waste water treatment systems - II. A prototype mathematical model based on kinetic selection and filamentous backbone theory. Water Research 34(9): 2535-2541.

Da Motta M, Pons M-N, Roche N and Vivier H (2001) Characterisation of activated sludge by automated image analysis. Biochemical Engineering 9(1): 165-173.

Eikelboom DH (1975) Filamentous organisms observed in activated sludge. Water Research 9(4): 365-388.

Ekama GA (1997) Secondary Settling Tanks: Theory, Modelling, Design and Operation, 1st edn. International Water Association, London.

Gerardi MH (2003) Settleability Problems and Loss of Solids in the Activated Sludge Process, 1st edn. Wiley, New Jersey, USA.

Govoreanu R, Saveyn H, van der Meeren P. and Vanrolleghem PA (2004) Simultaneous determination of activated sludge floc size distribution by different techniques. Water Science Technology 50(12): 39-46.

Jarvis P, Jefferson B and Parsons SA (2005) Measuring floc structural characteristics. Reviews in Environmental Science and Biotechnology 4(1-2): 1- 18.

Jenkins D, Richard MG and Daigger GT (1993) Manual on the Causes and Control of Activated Sludge Bulking and Foaming, 2nd edn. Lewis, Chelsea, MI, USA.

Lee SE, Koopman BL, Jenkins D and Lewis RF (1982) The effect of aeration basin configuration on activated sludge bulking at low organic loading. Water Science Technology 14(6/7): 407-427.

Liao BQ, Droppo IG, Leppard GG and Liss SN (2006) Effect of solids retention time on structure and characteristics of 
sludge flocs in sequencing batch reactors. Water Research 40(13): $2583-2591$.

Liwarska-Bizukojc E and Bizukojc M (2006) Effect of selected anionic surfactants on activated sludge flocs. Enzyme and Microbial Technology 39(4): 660-668.

Madoni P, Davoli D and Gibin G (2000) Survey of filamentous microorganisms from bulking and foaming activated-sludge plants in Italy. Water Research 34(6): 1767-1772.

Martins AMP, Pagilla K, Heijnen JJ and van Loosedrecht MCM (2005) Filamentous bulking sludge - a critical review. Water Research 38(4): 793-817.

Matlab (2004) Help file, htttp://www.mathworks.co.uk/access/ helpdesk/help/toolbox/images/(accessed 03/12/2005)

Nopens I, Biggs CA, De Clercq B, Govoreanu R, Wilén BM, Lant $P$ and van rolleghem PA (2002) Modelling the activated sludge flocculation process combining laser light diffraction particle sizing and population balance modeling (PBM). Water Science and Technology 45(6): 41-49.

Palm JC, Jenkins D and Parker DS (1980) Relationship between organic loading, dissolved oxygen concentration and sludge settlability in the completely-mixed activated sludge process.
Journal of the Water Pollution. Control Federation 52(10): 2484-2506.

Russ JC (1999) The Image Processing Handbook, 3rd edn. CRC Press, Boca Raton, FL, USA.

Sezgin M and Jenkins DA (1978) Unified theory of filamentous activated sludge bulking. Journal of the Water Pollution Control Federation 50(2): 362-381.

Tchobanoglous G, Burton FL and Stensel HD (2002) Wastewater Engineering, Disposal and Reuse, 4th edn. Metcalf and Eddy Incorporated, McGraw-Hill, Dubuque, IA, USA

Thompson G and Forster CF (2003) Bulking in activated sludge plants treating paper mill wastewaters. Water Research 37(11): 2636-2644.

Wilen B, Lumley D, Mattsson A and Mino T (2008) Relationship between floc composition and flocculation and settling properties studied at a full scale activated sludge plant. Water Research 42(16): 4404-4418

Wu J (2008) Characterization of activated sludge processes by particle and floc analysis. Doctoral thesis, Loughborough University.

\section{What do you think?}

To discuss this paper, please email up to 500 words to the editor at journals@ice.org.uk. Your contribution will be forwarded to the author(s) for a reply and, if considered appropriate by the editorial panel, will be published as discussion in a future issue of the journal.

Proceedings journals rely entirely on contributions sent in by civil engineering professionals, academics and students. Papers should be 2000-5000 words long (briefing papers should be 1000-2000 words long), with adequate illustrations and references. You can submit your paper online via www.icevirtuallibrary.com/content/journals, where you will also find detailed author guidelines. 